\title{
ACRL Statement on Professional Development
}

\section{Approved by the ACRL Board of Directors on July 8, 2000}

\author{
by the ACRL Professional Development Committee
}

\section{Executive summary}

Professional development is an important manifestation of the academic librarian's commitment to personal excellence. It is a necessary response to a rapidly changing environment. Although professional development is an individual responsibility, it thrives on partnership with the associations and the institutions that share common goals and values with academic librarians. The ACRL Statement on Professional Development is both declaration and mandate. Through it, the members and staff of ACRL declare our collective intent to strive for professional excellence through rigorous programs of lifelong learning and personal growth.

\section{The Statement on Professional Development}

The Association of College and Research Libraries (ACRL) is the professional organization for librarians and other information specialists in academic and research institutions throughout the world. Central to ACRL's mission is the responsibility to promote the "highest level of professional excellence" among its members. This Statement on Professional Development is designed:

- to raise awareness within the community of academic and research librarians of the shared nature of that responsibility;

- to foster dialog between ACRL members and the institutions which provide context and support for the work and growth of academic and research librarians; and

- to raise the bar against which ACRL members and staff measure their commitment to professional excellence through continued learning.

Librarians commit themselves to a program of continual growth that anticipates and complements the evolving information needs of our institutions and of society. They commit themselves—organizationally and individually - to lifelong learning and professional development.

At the same time, the professional development of academic and research librarians is a shared responsibility. Graduate schools recruit and educate candidates for the profession. Institutions hire librarians and benefit from their continued maturation and growth. Professional development is sustained by the enduring activities of organizations such as ACRL. In many ways, professional development is the embodiment of an ongoing process of personal mastery aided by organizational interest in, and support for, learning through partnerships. While each partner plays an important role in sustaining professional growth, the foundation for development must be personal commitment to closely held and clearly articulated values.

\section{Context for change}

Technology is reshaping the world of learning and of scholarly communication, and the effects on academic and research librarians are profound. Librarians are challenged to manage an exploding body of information, weaving electronic, print, and nonprint resources into a seamless fabric of services for constituents. Unlike their predecessors whose skills evolved along with scholarly commu- 


\section{Developing the Statement}

Periodically, ACRL's Professional Development Committee has struggled to define its role within the organization. Because the entire organization serves its members' professional development, the committee charge has not always been clearly distinguishable from the misston of the organization. Members during the late 1990s even seriously considered recommending the committee be abolished. It was then that they decided to embark on a journey of discovery to clarify the committee's role within ACRL and to give direction to future

Over the course of the next two-and-ahalf years, committee members surveyed ACRL members, conducted formal focus groups, and held informal discussion sessions in an attempt to learn how members defined professional development and what they believed ACRL's role in the professional development process should be.

In the course of this information gathering, the committee determined that a document formalizing our collective beliefs about

nication-gathering, organizing, storing, and retrieving-librarians now find themselves on the leading edge in the delivery of scholarly information. The availability of information resources marketed directly to the end-user is unprecedented. Never before has the responsibility for an informed citizenry seemed so central to the mission of librarians, nor its success so elusive.

The strategic position of librarians has never been more promising. Yet the challenges they face are staggering. While the great core of principles, practices, and values they espouse remains relevant, the skills and knowledge required to perform their jobs are constantly changing. Increasing diversity brings increased demand for interpersonal skills. The fragility of traditional materials threatens their future and hinders their use. Digital reproductions, material "born digitally," and ephemeral material are at risk of obsolescence, due to shifting standards and racing technology. These developments require increased technological skills to ensure professional development was needed. The "ACRL Statement on Professional Development" is the result of their work.

Over the course of this work, Lee Ketcham-Van Orsdel, Eastern University Kentucky, chaired the committee from 1998 to 2000. Other committee members who participated were John Collins III, Harvard College; David Dowell, Cuesta College; Jan Fortier, Marylhurst University; Geri Bunker Ingram, University of Washington; Sally Kalin, Pennsylvania State University; Johnnieque Love, Texas A\&M University; Sandra Ready, Minnesota State University, Mankato; Jemmifer Dorner, Ball State University; and Juana Young, University of Arkansas. Mary Ellen Davis served as ACRL staff liaison.

Further information about the committee's current initiatives may be obtained by contacting Geri Bunker Ingram, current committee chair, at the University of California San Diego, UCSD Libraries, 9500 Gilman Drive $\# 0175$, La Jolla, CA 92093.

appropriate and effective action on the part of information professionals.

Academic librarians can play a key role in managing these issues, but only through a thorough an ongoing commitment to continually learning new concepts and skills. Providing leadership for the academy will demand that whole library organizations commit to building competence in teamwork and in systemwide thinking. Only through close, working alliances with administration, faculty, students, and information technology professionals will librarians develop the perspective necessary for leadership.

\section{Responsibilities of academic and research librarians}

Professional excellence is an individual, rather than a corporate, characteristic. Although organizations can be described as "professional" or "excellent," their collective excellence results from the work of individuals who practice the highest principles of the profession. Learning, which is the key to acquiring and 
maintaining individual excellence, is ultimately the responsibility of the individual.

Over a lifetime, each librarian develops along parallel growth paths of career experience, personal development, contextual understanding, and in-depth expertise. Learning is the event that drives the librarian further along each of these continuums. For maximum effectiveness, learning needs to be thoughtfully managed. It is the responsibility of each academic librarian to identify the professional and personal skills and knowledge needed for current and anticipated responsibilities; to continuously assess the skills, aptitudes, and knowledge they possess; and to canonize that awareness into personal learning strategies. Librarians should aggressively seek opportunities to learn from a variety of sources in related professions and in professions that have not traditionally been associated with libraries.

Partners in information management have much to offer. The National Research Council's (NRC) Committee on Information Technology Literacy, for example, has codified the complex array of knowledge and skills, which constitute information fluency into a taxonomy of three developmental groupings: contemporary skills, foundational concepts, and intellectual capabilities. They distinguish between intellectual and conceptual foundations of understanding, which are timeless, and skills, which change continuously throughout a lifetime. ${ }^{1}$

Academic and research librarians have a responsibility to share what they have learned through writing, speaking, mentoring, and modeling, in order to facilitate the learning of their colleagues and the advancement of the profession. In addition, they should articulate professional development needs to their employers, to ACRL, to library educators, and to other professional organizations which have relevant knowledge and skills to share.

\section{Responsibilities of ACRL}

ACRL has a leadership role in setting high expectations for its members relative to continuous learning. Members expect ACRL to commit substantial resources to creating affordable, accessible, dynamic and relevant educational opportunities, exploiting new modes of delivery as they emerge. Although it can provide only a portion of the professional development needs of its members, ACRL supports its members in systematically identifying and participating in innovative professional development programs.

ACRL plays a role in facilitating self-directed learning among its members. ACRL's elected leaders, in concert with association staff, should enhance opportunities for professional exchange among the membership by expanding venues where ideas can be exchanged, such as conferences, chapter meetings, publications and electronic forums. With advice from the membership, ACRL leadership and staff should develop assessment tools to assist members in evaluating their learning styles, skills and knowledge and explores opportunities to define core competencies when appropriate.

ACRL should continue to emphasize collaboration with its partners in higher education, with graduate schools of library education, and with other organizations that share the interests of academic librarians, for the express purpose of increasing learning opportunities for its members. The association's leaders should monitor and/or research trends in higher education relative to academic libraries, changing professional expectations, workplace needs of the membership, and other relevant issues. These findings should be regularly disseminated to the membership, to graduate schools, and to other partners as appropriate.

\section{Responsibilities of professional educators}

Educators in graduate schools of library service, information science, and information studies play a critical role in the lifelong development of academic librarians. They construct graduate curricula that prepare students for a continuum of personal and professional learning experiences throughout their careers. Such curricula might include assessment of learning styles and personal aptitudes; skillbuilding in leadership, team work, critical thinking, and decision-making; and repeated emphasis on the necessity of lifelong learning in the career of an information professional.

Library educators nurture the growth of their graduates and of the professional communities within which they reside. They 
should disseminate scholarly research and facilitate growth in ways that support the profession. They should continually assess the professional development needs of librarians, offering opportunities for learning in venues and modes that are accessible to career librarians.

\section{Responsibilities of academic institutions}

Through enlightened self-interest, academic institutions should appreciate the importance of-and materially support-professional development for academic librarians. Colleges and universities should demonstrate their commitment to personal mastery and continuous learning, e.g., through financial support, ad- ministrative leave, and/or flexible work schedules for academic librarians engaged in learning activities. They should also measure, recognize and reward exceptional individual and team performance. Institutions have a further responsibility to create, sponsor or offer learning events for their professional staff.

\section{Note}

1. Being Fluent with Information Technology (http://www.nap.edu/books/030906399X/ html/) (1999), Executive Summary, p. 4. Produced by the National Research Council's Commission on Physical Sciences, Mathematics, and Applications. Print edition available from $\mathrm{Na}$ tional Academy Press, Washington, D.C.
("Acquiring a 9-milliontb book" continued from page 892)

overworked and romanticized, they project sense of immediacy that is almost unnerving.

We were all very pleased with the $A b$ original Port Folio, but it clearly needed conservation work. We consulted with Gillian Boal and Nancy Harris in the Library's Conservation Laboratory. Boal would have to deal with repairing the binding and Harris would have to fix the tears in three plates that had been clumsily mended with adhesive tape, as well as some other less difficult problems. Working together, we laid out a plan of conservation work and a timetable for its completion.

The Aboriginal Port Folio had its first public viewing on Cal Day, April 15, and was very much admired. This fall it was prominently featured in the exhibition "Images of Native Americans" in the Bancroft Gallery and runs from September to early December. It's displayed in company with McKenney and Hall, Catlin, Bodmer, and a wealth of other depictions of Native Americans.

\section{Applications/nominations invited for C\&RL editor}

Applications and nominations are invited for the position of editor of College \& Research Libranies ( $C \in R D$ ), the bimonthly, scholarly research journal of the Association of College and Research Libraries (ACRL). The editor is appointed for a three-year term, which may be renewed for an additional three years. Applicants must be a member of ALA and ACRL. Qualifications inclucle professional experience in academic libraries, a record of scholarly publication, editing experience, an ability to meet publication deadlines, an understanding of the scholarly communication process, and a broad knowledge of the issues confronting academic libraries.

Some funding for editorial assistance and travel to relevant conferences is available, and there is a small honorarium for the editor.
Appointment will be made by the ACRL Board of Directors at the 2001 Annual Conference upon the recommendation of the search committee and of the ACRL Publications Committee. The incoming editor will serve a one-year internship with the current editor before assuming full responsibility for $G G R L$ in July 2002.

Nominations or resumes and letters of application, including the names of three references, should be sent to:

C\&RL Search Committee

c/o Hugh Thompson, Director of Publications ACRL

50 East Huron Street

Chicago, IL 60611

hthompson@ala.org

The deadline for receipt of applications is December 6, 2000.

Finalists will be interviewed at the Midwinter Meeting in January 2001. 


\section{New Releases from APA}
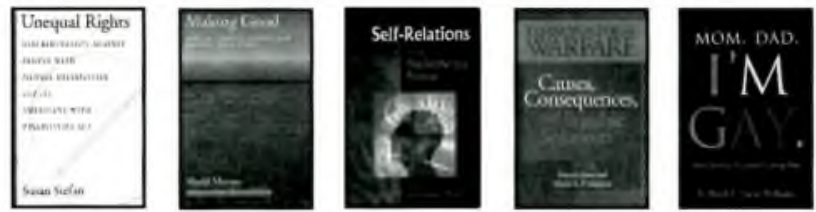

Unequal Rights:

Discrimination Against People With Mental Disabilities and the Americans with Disabilities Act

Susan Stefan

2000. About 405 pages. Hardcover.

Part of the Law and Public Policy: Psychology and the Social Sciences book series.

APA Member/Affiliate: \$39.95; List: \$49.95| Item \# 431637A; ISBN: 1-55798-681-9

\section{Making Good:}

How Ex-Convicts Reform and Rebuild Their Lives

Shadd Maruna

2001. About 264 pages. Hardcover.

APA Member/Affiliate: \$34.95; List: \$39.95 | Item \# 43। 645A; ISBN: I-55798-731-9

Self-Relations in the Psychotherapy Process

Edited by J. Christopher Muran

2001. About 400 pages. Hardcover

APA Member/Affiliate: \$39.95: List: \$49.95| Item \# 43। 648A; ISBN: 1-55798-733.5

Ethics in HIV-Related Psychotherapy:

Clinical Decision-Making in Complex Cases

Edited by John R. Anderson and Robert L. Barret

2001. About 376 pages. Hardcover.

APA Member/Affiliate: \$34.95; List: \$39.95 | Item \# 4312320; ISBN: 1-55798-722-X

School Refusal Behavior in Youth:

A Functional Approach to Assessment and Treatment

Christopher A. Kearney

2001. About 264 pages. Hardcover.

APA Member/Affiliate: $\$ 34.95$; List: $\$ 39.95$ | Item \# 431650A; ISBN: 1-55798-699-1

The Nature of Executive Leadership:

A Conceptual and Empirical Analysis of Success

Stephen J. Zaccaro

2001. About 464 pages. Hardcover.

APA Member/Affiliate: \$39.95; List: \$49.95| Item \# 431646A; ISBN: 1-55798-732-7

Mom, Dad. I'm Gay:

How Families Negotiate Coming Out

Ritch C. Savin-Williams

2001. About 272 pages. Hardcover.

APA Member/Affiliate: $\$ 34.95$; List: $\$ 39.95$ | Item \# 431766A; ISBN: $1-55798-741$-6

Ethnopolitical Warfare:

Causes, Consequences, and Possible Solutions

Edited by Daniel Chirot and Martin E. P. Seligman

2001. About 400 pages. Hardcover.

APA Member/Affiliate: \$39.95; List: $\$ 49.95$ | Item \# 431649A; ISBN: 1-55798-737-8

American Psychological Association

\section{1-800-374-2721 • www.apa.org/books}

